\title{
The Role of Rewilding in Landscape Design for Conservation
}

\author{
Richard T. Corlett ${ }^{1}$
}

Published online: 24 August 2016

(C) Springer International Publishing AG 2016

\begin{abstract}
Rewilding means returning a non-wild area back to the wild. It implies a reduction or cessation of human control in favour of allowing nature to take care of itself. The concept originated in North America, where it was initially focused on reconnecting existing wilderness areas and re-establishing populations of large carnivores and other large vertebrates. The modern literature is dominated by European studies, however, in which rewilding is seen as a management option for the increasing areas of abandoned agricultural land. Although modern rewilding looks forward to a future wildness that is not necessarily the same as the past, evidence from past ecosystems gives inspiration and support for a hands-off approach. Late Pleistocene ecosystems provide a major challenge since they show the irreplaceable roles of the now largely extinct megafauna. Large-scale rewilding will benefit some charismatic large vertebrates, but probably at the expense of many disturbance-dependent species, with the overall impact likely to differ in different regions. Other potential problems include the loss of valued biocultural landscapes and an increase in human-wildlife conflicts. Benefits may include increased recreational opportunities, enhanced ecosystem services, and greater resilience, as well as less quantifiable social benefits and spiritual values. Rewilding science needs to catch up with rewilding practice, and there is an urgent need for replicated, large-scale, long-term experiments.
\end{abstract}

This article is part of the Topical Collection on Landscape Design and Planning for Ecological Outcomes

Richard T. Corlett

corlett@xtbg.org.cn

1 Center for Integrative Conservation, Xishuangbanna Tropical Botanical Garden, Chinese Academy of Sciences, Menglun, Yunnan 666303, China
Keywords Conservation biology $\cdot$ Land abandonment . Reintroduction $\cdot$ Restoration ecology $\cdot$ Wilderness

\section{Introduction}

The prefix 're' means 'back' or 'again' in English and many other European languages, thus rewilding implies returning a non-wild area back to the wild [1]. This is the definition adopted in this review, except that I have followed normal usage in also including increases in relative wildness, i.e., from less wild to more wild. Wildness in this context implies autonomy, spontaneity, self-organization, and the absence of human control. Within this broad definition, however, rewilding has been used in a variety of ways, reflecting the short history of the field and the absence of any single authority, such as the IUCN provides for reintroduction and the Society for Ecological Restoration for restoration.

The term was first used 25 years ago in North America for the restoration of large, connected, wilderness areas that support large, wide-ranging animals, with an emphasis on carnivores: a concept that has been summarized as 'cores, corridors, and carnivores' [2]. When the term was adopted in Europe, however, large carnivores were usually de-emphasized, and the absence of sustained human intervention became the core concept $[3,4]$. Indeed, rewilding in Europe can be entirely passive, the opposite of what is implied by 'landscape design' [5]. Moreover, Europe largely lacks the existing wilderness areas that form the core of most North American rewilding proposals, while it has extensive biocultural landscapes whose maintenance has been a major focus of conservation activity. These differences in emphasis are reflected in the ambitions of the major organizations promoting and coordinating rewilding. The Wildlands Network in North America (www.wildlandsnetwork.org) focuses on the creation of large protected corridors linking existing protected 
areas from Canada to Mexico, while Rewilding Europe (www. rewildingeurope.com) is currently focusing on ten rewilding areas, which it hopes will become models for future expansion of the rewilding program. European studies dominate the recent rewilding literature, with an emphasis on rewilding as a potential management option for abandoned agricultural land. However, the scattered studies from the rest of world often look back to the North American origins of the concept.

This review focusses largely on the science, but it is important to acknowledge that rewilding is not only-indeed, not mainly - a scientific issue. Most rewilding papers in the scientific literature are opinion pieces, not research outputs, and empirical data to back up the views expressed is largely lacking $[6,7]$. There is a large romantic element to rewilding, which can be used to prop up weak or incomplete science, making it difficult to assess the robustness of predictions. Moreover, charismatic proponents, popular books, and media coverage have created a popular enthusiasm that has pushed rewilding forward while leaving the science to catch up [4].

\section{Opportunities for Rewilding}

Although rewilding was first proposed for existing wilderness areas in North America [2], the rapid growth in scientific and public interest in the concept in recent years has been driven largely by the expanding conservation opportunities that arise when agricultural land (including both crop and pasture land) is abandoned [8]. Similar land abandonment is happening in many parts of the world for a variety of reasons that can generally be linked with economic growth favoring the concentration of agricultural activity on the most productive land [9-14]. In Europe, predictions for the amount of land to be abandoned over coming decades vary widely, but it is clear that the land potentially available for rewilding will be concentrated inalthough not confined to - the uplands $[10,15,16]$.

Rewilding started big, with the minimum area that could be rewilded determined by the very large area requirements of viable carnivore populations [2]. In contrast, in the broader definition used here, it is possible to increase the wildness of any area, simply by reducing or removing human control. However, the consequences and potential benefits of rewilding are still highly scale-dependent, with the possibilities generally increasing with size. Indeed, it could be argued that smaller areas $(<1000 \mathrm{ha}$ ?) cannot be truly rewilded, because their high edge to area ratios make autonomy from the surrounding, managed, areas impossible.

\section{Rewilding and Restoration}

Rewilding is sometimes considered to be a special case of ecological restoration, which can be broadly defined as 'assisting the recovery of an ecosystem that has been degraded, damaged or destroyed' [17]. In terms of methods and philosophy, however, it is clearly distinct. While restoration ecology uses human interventions to achieve pre-determined goals that cannot be attained by other means, rewilding uses the minimum possible human intervention in order to allow ecosystems to develop spontaneously. In practice there is a continuum, from high-input restoration to entirely passive rewilding, with most applications some distance from these extremes. To some extent the choice of approach is simply a matter of practicality, since extreme restoration is only possible for small areas, and passive rewilding is possible on any scale, but is more likely to produce the desired outcome - a diverse, native-dominated, self-maintaining ecosystem - in large, connected areas. However, differences in philosophical framing may be decisive at scales where different intensities of intervention are possible. Restoration has traditionally been defined by a historically-based reference frame $[18,19]$, while rewilding, despite its fundamentally nostalgic origins in North America, usually has a clear future orientation in which the past is more an inspiration than a template [15].

\section{Trophic Rewilding}

Much of the rewilding literature focuses more on restoring ecological functions than on the species themselves [20]. There is increasing evidence that the loss of the largest herbivores and carnivores - the megafauna-since the Late Pleistocene has impacted ecosystems in multiple ways, from species composition and trophic structure to biogeochemical cycling [7]. Humans likely played a crucial role in most of these losses [21] and restoration of megafaunal functions has been a major theme in the arguments for rewilding. The original 'cores, corridors, and carnivores' concept was based on the idea of top-down ecological control through trophic cascades: large carnivores control large herbivores and mesopredators, while large herbivores in turn control the vegetation [2]. The reintroduction of wolves to Yellowstone National Park in the USA has been the flagship for this approach $[4,22]$. However, although the proposed top-down mechanism may be true in some cases, there is little direct evidence for its generality [22, 23]. Moreover, the trophic cascades observed in some modern ecosystems may be at least partly an artifact of the Late Pleistocene extinctions of the megaherbivores $(>1000 \mathrm{~kg})$, which are almost immune to predation as adults and can thus attain high densities without topdown regulation [24].

In Europe, where rewilding has focused more on large herbivores than carnivores, it has been argued that they could maintain the biodiverse open habitats in Europe which forest recovery would otherwise threaten [25]. However, while there is evidence that the diverse and abundant large herbivore guild 
in the last interglacial (including extinct species of elephant and rhinoceros $>1000 \mathrm{~kg}$ ) maintained a mosaic of closed and open habitats, the depleted herbivore assemblage of the early Holocene (in which the European bison and extinct auroch were the largest species) was apparently insufficient to slow the expansion of closed forest [26]. Similar conclusions may apply to North America (all species $>600 \mathrm{~kg}$ extinct [21]) and other regions that have lost all or most of their megaherbivore fauna, such as the Cerrado and Pantanal in South America [27]. Model simulations suggest that the diverse and now entirely extinct megaherbivore fauna of Late Pleistocene South America would have reduced tree cover in the extensive savanna ecosystems, as happens today in Africa [24]. Overall, both modern experiments - mostly in Africa - and paleorecords suggest that the largest herbivores would have maintained more open habitats, particularly in fertile lowland areas, than would have occurred in their absence [28].

\section{Pleistocene Rewilding, Taxon Substitution, and de-Extinction}

The elimination of most of the largest species of herbivores and carnivores from the Earth's surface in the last 100,000 years poses a dilemma for rewilding proponents. In most parts of the world, any Holocene baseline for rewilding represents an ecosystem that has already lost many of the functions and processes that depended on having an intact megafauna [26]. The proposed solution in North America was to push the baseline back to the Late Pleistocene (c. 15,000 years ago), before the extinctions that accompanied the arrival of humans in the New World [29]. Other dates make more sense in areas reached by Homo sapiens earlier or later, from around 50,000 years ago (New Guinea and Australia) to less than 500 years ago (Mauritius). The Late Pleistocene also differed significantly in climate from the present day, so an argument could be made for the last interglacial (c. 130,000-115,000 years ago) as the last time an intact fauna existed in a modern climate [26].

Where species are only locally extinct, then reintroduction from extant wild or captive populations is theoretically possible (e.g., the hippopotamus to the River Thames in England), although local adaptations will have been lost. In many places, however, the megafaunal extinctions were global losses. In these cases, the only way currently available that the functional composition of the fauna can be restored is by taxon substitution (or ecological replacement): the introduction of a functional replacement for the missing species [27, 29]. $A$ priori, an extant close relative should be preferred, if available, since relatives are more likely to share both known and unknown ecological functions. However, where entire clades have been lost, as with the Pleistocene South American ungulates [30], this is impossible. Short-term successes for ecological replacement have been reported for giant tortoises on oceanic islands $[4,31,32]$, though the long-term impacts of these introductions are, as yet, unknown. Moreover, the introduction of giant tortoises to islands is relatively easy, no threat to people or crops, and potentially reversible, but this will not be true of many other proposed introductions. Rewilding North America or Europe with African lions or one of the extant species of elephant, in contrast, will only ever be possible behind fences.

An increasingly plausible alternative to taxon substitution is to recreate missing species, in appearance, function, and potentially, genetic identity [33-35]. De-extinction of extinct species using synthetic biology tools has gone from science fiction to a serious prospect within the last few years, and could transform conservation by allowing the reintroduction of species lost decades to millennia ago. The passenger pigeon, heath hen, great auk, woolly mammoth, and others are under discussion [36]. Although the re-establishment of longextinct species carries risks, including unexpected species interactions, these risks are no greater than with other conservation interventions and probably less than with taxon substitution [33]. Additional uncertainties will arise, however, if the (re)introduced organisms are not genetically identical to the original species, but have been assembled from fragments of ancient DNA sequences patched with DNA from a living relative.

\section{Passive Rewilding}

Passive rewilding has obvious attractions, but its adoption as conservation policy requires a willingness to accept whatever happens. In theory, doing nothing except stopping any management activities achieves instant rewilding, since human control ceases and the system becomes autonomous [5]. In practice, however, there will always be leakage from adjacent or distant managed areas, including anthropogenic changes in atmospheric composition and climate, increased deposition of nitrogen and other nutrients, air and water pollution, invasive species, and emerging infectious diseases [1]. The impacts of this inwards leakage will be relatively greater the smaller the area that is being rewilded. There are also potential problems with leakage outwards from rewilded areas into the surrounding managed landscapes, including the potentially dangerous and damaging large vertebrates discussed below, but also invasive species that may proliferate without controls.

\section{Rewilding Novel Ecosystems}

A novel ecosystem can be broadly defined as an ecosystem that differs from the one that previously existed at the site. The term is usually restricted to ecosystems that have been 
modified by human activities and usually implies that the new state is self-maintaining, thus excluding agricultural crops [1, 11]. Humans can create novelty in ecosystems in many ways, but the literature largely focuses on invasive species, particularly of plants. A novel ecosystem may be rewilded in the hope that this will control the invaders, by the formation of a closed woody canopy or through the reintroduction of large grazers [31]. David Bowman has proposed using ecological replacements for Australia's extinct megafauna to control invasive aliens, particularly aggressive grasses [37]: using novelty to control novelty. Australia's previous disastrous experiences with invasive vertebrates, including rabbits, cats, and foxes, warn against adding to the list, but elephants and rhinoceroses would presumably be easier to control than smaller species. Alternatively, rather than being controlled, alien invaders may be accepted as permanent components of the "new wildness' [5].

\section{Benefits of Rewilding}

In most landscapes, the impacts of rewilding on biodiversity will be mixed, with both winners and losers. In regions, such as the humid tropics, where most native species are unable to use anthropogenic habitats, the winners are expected to predominate, but in Europe, where many species are adapted to open or semi-open habitats, losers often outnumber winners, at least locally $[38,39]$. The recolonization or reintroduction of large herbivores may help to maintain some open habitats and prescribed burning may be useful in some landscapes [40]. The native biodiversity of Europe and other areas persisted through the early Holocene forest maximum, but the areas available for rewilding today do not include all facets of the landscape and may thus not include the specific refuges from forest closure that a particular species requires. Overall, therefore, the biodiversity case for rewilding in Europe often depends on the prioritization of large, charismatic vertebrate species over smaller, disturbance-dependent plants and animals. These latter species, however, can potentially be accommodated in smaller areas of low-intensity agriculture managed for this purpose.

Economic benefits from rewilding potentially include the sustainable production of timber, firewood, and wild meat, if these activities are allowed, and opportunities to develop ecotourism and nature-based recreation [41]. These potential benefits are relatively minor at a national or regional scale, but can be locally significant, as a source of both income and employment. Rewilding will also often enhance a variety of ecosystem services, including the supply of freshwater, reduction in soil erosion, flood prevention, and the removal of air pollutants [41].Where rewilding increases woody plant cover, as will usually be the case in Europe, carbon sequestration will increase [42]. Moreover rewilding is likely to be cheaper to establish and maintain than efforts to preserve traditional highdiversity biocultural landscapes [41, 42]. Where large areas are rewilded, the combination of connectivity and species diversity may enhance resilience to climate change.

The social benefits of rewilding are harder to quantify, except for those like hunting opportunities and guided nature recreation for which users pay. The health benefits of contact with nature are well-studied [43], but the additional benefits, if any, derived from large and relatively remote wild areas over those derived from tamer and more accessible sites is unknown. The spiritual benefits of natural experiences, however, appear to be enhanced by solitude and naturalness [44], suggesting that these could be increased by rewilding, although solitude, by definition, can only be enjoyed by a few people at a time. The benefits from wild areas may not even require direct contact: even for people who do not expect to see them, knowing that wolves run free in their region can be considered as a valuable wild experience in itself [45]. Moreover, it can be argued that both direct and indirect contact with wildness will become more desirable and more necessary the more artificial the human world becomes [5].

\section{Problems and Challenges}

Rewilding has attracted critics from a wide range of sources, on scientific, legal, political, bureaucratic, emotional, economic, cultural and other grounds, leading to an unusually-for conservation issues - vigorous public debate $[3,45,46]$. As a conservation strategy, the minimum sustained intervention approach of rewilding faces multiple challenges in a rapidly changing world. Wildness and lack of human control imply the possibility of surprises, which conflicts with both the traditional preservationist-restorationist approach of conservation and the resulting audit-driven culture $[8,46]$. How can the question 'Were the objectives achieved?' be answered if the objectives are unclear? Lack of control may also conflict with alternative conservation targets, including the promotion of particular species and the control of others.

In Europe, the biggest issue is often the loss of traditional biocultural landscapes that are valued for both their cultural significance and the biodiversity they support, and whose continued existence is supported by current EU policies [12, 39, 47, 48]. Similar concerns have been expressed in Japan [49]. Areas protected for their biodiversity value in Europe are rarely 'wilderness' in the North American sense, but more often landscapes that were created and are still maintained by human activities [50]. Others have argued, however, that preserving such 'museum landscapes' is impractical and that rewilding will create new opportunities for biodiversity on a larger scale [51].

Actual or potential human-wildlife conflicts, or perceptions of such a risk, are another big issue, particularly in North 
America, but increasingly in Europe as populations of large, potentially dangerous vertebrates recover [4, 52-54]. Sweden probably has more large vertebrates today than at any time in the last 500 years and possibly much longer [55]. Wolves threaten domesticated livestock throughout their range [53] and large herbivores, such as the European bison, damage farm crops [56]. Megaherbivores such as elephants are particularly dangerous and damaging, as farmers in Africa and Asia know from experience [57]. Increased interactions between wildlife and humans and domestic animals may also lead to disease transmission, or at least perceptions that this is a risk [55]. In seasonally dry climates, increased fire risk is an additional hazard, particularly in the early stages of biomass recovery [16].

Additional challenges in many parts of the world come from on-going economic development, even in areas where agriculture is in decline. For example, the high-density road network over much of Europe may limit rewilding opportunities because avoidance of even minor roads by many vertebrates limits range expansion by recovering populations and reduces the effective area for conservation [58, 59].

Another important issue, which has received relatively little attention in the literature, is that rewilding a significant proportion of the land implies intensified use of the rest: a 'land sparing' rather than 'land sharing' approach to conservation [46]. While the scientific literature generally supports land sparing as a conservation strategy [60, 61], some critics have been dismayed at the reinforcement of a traditional nature-culture dichotomy that this implies [62]. Alternative models for conservation in Europe aim to encourage coexistence of people and nature in multi-use landscapes, rather than their separation into wild and non-wild landscapes [63]. This is partly a question of scale, since both models accept that there will be wild and less wild areas, but the wilder elements in a shared landscape are usually too small to support the more sensitive species that benefit most from large-scale land sparing [60].

Finally, a frequent criticism of smaller-scale rewilding efforts is that they are as planned and artificial as other land-uses: an engineered nature that lacks the spontaneity of the real thing [3]. This, however, is an anthropocentric perspective, as visitors to Oostvaardersplassen in the Netherlands can experience. From the outside, it is small (5600 ha) area, artificially reclaimed from the sea, to which 'fake' wild cattle and horses, as well as real deer, have been introduced to recreate a semblance to a Late Pleistocene ecosystem [64]. Inside the fence, however, these animals live spontaneous, autonomous lives largely free from human control, and have helped create a habitat for native plant and animal species that are rare elsewhere. People have set it up and continue to limit the movements of the species that cannot cross the fence, but it is certainly wild in most senses of the term.

\section{Research Needs}

In view of the large areas that are now being proposed for rewilding projects, it is essential that the science of rewilding is put on a sound footing. Decisions will no doubt continue to be made largely on non-scientific grounds, but a scientific understanding of the processes involved will help anticipate problems and optimize any interventions that are required. Only manipulative experiments can produce the level of scientific confidence required, and these will need to be both large-scale and long-term [28, 35]. They need to include both enclosures and exclosures, keeping large vertebrates in or out of fenced areas, as well as no-intervention and business-asusual controls. Ideally, these experiments would be replicated in each region, and repeated across a range of different physical and natural environments. In practice, a purely experimental network is unlikely because of the expense, but planned and future rewilding projects can, if carefully designed, function also as experiments. Moreover, given the public interest in rewilding, this approach is likely to garner considerable support.

Reintroductions of large carnivores require such large areas that replicated experiments will normally be impractical. In this case the best alternative is to use before-after observations with planned or spontaneous reintroductions, controlling statistically for confounding variables [22]. The impacts of other species, such as wild boar, can be studied in relatively small enclosures [65], while exclosures can give useful results for plants in small plots [66]. In addition to experiments, there is also a need to for observational studies that focus on specific processes, such as browsing, grazing, and seed dispersal by megaherbivores. Parts of Africa and India provide the best opportunities today to do this in near-intact ecosystems.

\section{Conclusions}

Rewilding efforts will undoubtedly continue to expand, since their support is based on a strong emotional appeal rather than any scientific arguments. Perhaps the biggest question is whether rewilding will be seen increasingly as a substitute for traditional preservationist-restorationist approaches to conservation or only as a supplement to these. Is it one end of an intervention continuum or an entirely separate approach? If the default becomes 'allowing nature to take care of itself', should we then intervene when this has unexpected and undesired consequences? Moreover, the concept of trophic rewilding has raised questions that were not anticipated in the early literature. We can probably learn to live with wolves and bison, but a complete Late Pleistocene megafauna would almost certainly need to be confined behind fences. Is our target for rewilding 'all that nature can be' or just 'all the nature we can live with'? In densely settled landscapes, like those of most of Europe, some degree of 
compromise seems inevitable, particularly when the areas available for rewilding are small and isolated. Even in urban areas, however, having areas that are outside on-going human control is an attractive option. Disagreements will continue, but both landscape ecology and conservation biology have already been reinvigorated by these debates.

Acknowledgments I am grateful to Alice Hughes, David Dudgeon, Gilbert Price, Julien Louys, Stuart Hawkins, and Philip Piper for useful discussions, initially as part of the ANU Research School of Asia and the Pacific (RSAP) Past Environments of the Asia/Pacific workshop, and for my graduate students whose projects first inspired my interest in this topic. The author was funded by the 1000 Talents Program of the State Administration of Foreign Experts Affairs (WQ20110491035).

\section{Compliance with Ethical Standards}

Conflict of Interest The corresponding author states that there is no conflict of interest.

Human and Animal Rights and Informed Consent No studies on animal or human subjects were performed for this article.

\section{References}

1. Corlett RT. Restoration, reintroduction, and rewilding in a changing world. Trends Ecol Evol. 2015;31(6):453-62.

2. Soulé ME, Noss R. Rewilding and biodiversity. Wild Earth. 1998;Fall:2-11.

3. Bulkens M, Muzaini H, Minca C. Dutch new nature: (re)landscaping the Millingerwaard. J Environ Plann Manag. 2015:1-18.

4. Lorimer J, Sandom C, Jepson P, Doughty C, Barua M, Kirby KJ. Rewilding: science, practice, and politics. Annu Rev Environ Resour. 2015;40:39-62.

5. Schnitzler A. Towards a new European wilderness: Embracing unmanaged forest growth and the decolonisation of nature. Landsc Urban Plan. 2014;126:74-80.

6. Carey J. Core concept: rewilding. Proc Natl Acad Sci U S A. 2016;113(4):806-8

7. Malhi Y, Doughty CE, Galetti M, Smith FA, Svenning J-C, Terborgh JW. Megafauna and ecosystem function from the Pleistocene to the Anthropocene. Proc Natl Acad Sci U S A. 2016;113(4):838-46.

8. Pereira HM, Navarro ML, editors. Rewilding European landscapes. Berlin: Springer; 2015.

9. Queiroz C, Beilin R, Folke C, Lindborg R. Farmland abandonment: threat or opportunity for biodiversity conservation? A global review. Front Ecol Environ. 2014;12(5):288-96.

10. Kallimanis AS, Touloumis K, Tzanopoulos J, Mazaris AD, Apostolopoulou E, Stefanidou S, et al. Vegetation coverage change in the EU: patterns inside and outside Natura 2000 protected areas. Biodivers Conserv. 2014;24:579-91.

11. Martinuzzi S, Gavier-Pizarro GI, Lugo AE, Radeloff VC. Future land-use changes and the potential for novelty in ecosystems of the United States. Ecosystems. 2015;18(8):1332-42.

12. Terres J-M, Scacchiafichi LN, Wania A, Ambar M, Anguiano E, Buckwell A, et al. Farmland abandonment in Europe: Identification of drivers and indicators, and development of a composite indicator of risk. Land Use Policy. 2015;49:20-34.
13. Osawa T, Kohyama K, Mitsuhashi H. Multiple factors drive regional agricultural abandonment. Sci Total Environ. 2016;542:478-83.

14. Poore JAC. Call for conservation: abandoned pasture. Science. 2016;351:132.

15. Navarro LM, Pereira HM. Rewilding abandoned landscapes in Europe. Ecosystems. 2012;15(6):900-12.

16. Lasanta T, Nadal-Romero E, Arnáez J. Managing abandoned farmland to control the impact of re-vegetation on the environment. The state of the art in Europe. Environ Sci Pol. 2015;52:99-109.

17. SER. SER International Primer on Ecological Restoration. Tucson: Society for Ecological Restoration International; 2004.

18. Balaguer L, Escudero A, Martin-Duque JF, Mola I, Aronson J. The historical reference in Restor Ecol: Re-defining a cornerstone concept. Biol Conserv. 2014;176:12-20.

19. Higgs E, Falk DA, Guerrini A, Hall M, Harris J, Hobbs RJ, et al. The changing role of history in Restor Ecol. Front Ecol Environ. 2014;12:499-506.

20. Sandom CJ, Macdonald DW. What next? Rewilding as a radical future for the British countryside. In: Macdonald DW, Feber RE, editors. Wildlife conservation on farmland. Managing for nature on lowland farms. Oxford: Oxford University Press; 2015. p. 291-312.

21. Smith FA, Doughty CE, Malhi Y, Svenning J-C, Terborgh J. Megafauna in the earth system. Ecography. 2016;39(2):99-108.

22. Ford AT, Goheen JR. Trophic cascades by large carnivores: a case for strong inference and mechanism. Trends Ecol Evol. 2015;30(12):725-35.

23. Ripple WJ, Estes JA, Beschta RL, Wilmers CC, Ritchie EG, Hebblewhite M, et al. Status and ecological effects of the world's largest carnivores. Science. 2014;343(6167):151-8.

24. Doughty CE, Faurby S, Svenning J-C. The impact of the megafauna extinctions on savanna woody cover in South America. Ecography. 2016;39(2):213-22.

25. Vera FWM. Large-scale nature development-the Oostvaardersplassen. Br Wildl. 2009;20:28-36.

26. Sandom CJ, Ejrnæs R, Hansen MDD, Svenning J-C. High herbivore density associated with vegetation diversity in interglacial ecosystems. Proc Natl Acad Sci U S A. 2014;111(11):4162-7.

27. Galetti M. Parks of the Pleistocene: recreating the Cerrado and Pantanal with megafauna. Natureza \& Conservação. 2004;2:93-100.

28. Bakker ES, Gill JL, Johnson CN, Vera FWM, Sandom CJ, Asner $\mathrm{GP}$, et al. Combining paleo-data and modern exclosure experiments to assess the impact of megafauna extinctions on woody vegetation. Proc Natl Acad Sci U S A. 2016;113(4):847-55.

29. Donlan CJ, Berger J, Bock CE, Bock JH, Burney DA, Estes JA, et al. Pleistocene rewilding: an optimistic agenda for twenty-first century conservation. Am Nat. 2006;168(5):660-81.

30. Welker F, Collins MJ, Thomas JA, Wadsley M, Brace S, Cappellini E, et al. Ancient proteins resolve the evolutionary history of Darwin's South American ungulates. Nature. 2015;522:81-8.

31. Griffiths CJ, Zuel N, Jones CG, Ahamud Z, Harris S. Assessing the potential to restore historic grazing ecosystems with tortoise ecological replacements. Conserv Biol. 2013;27(4):690-700.

32. Hunter EA, Gibbs JP. Densities of ecological replacement herbivores required to restore plant communities: a case study of giant tortoises on Pinta Island. Galapagos Restor Ecol. 2014;22:248-56.

33. Donlan J. De-extinction in a crisis discipline. Front Biogeogr. 2014;6(1).

34. Seddon PJ, Moehrenschlager A, Ewen J. Reintroducing resurrected species: selecting DeExtinction candidates. Trends Ecol Evol. 2014;29(3):140-7.

35. Svenning J-C, Pedersen PBM, Donlan CJ, Ejrnæs R, Faurby S, Galetti M, et al. Science for a wilder Anthropocene: synthesis and future directions for trophic rewilding research. Proc Natl Acad Sci U S A. 2016;113(4):898-906.

36. Charo RA, Greely HT. CRISPR critters and CRISPR cracks. Am J Bioeth. 2015;15(12):11-7. 
37. Bowman D. Bring elephants back to Australia? Nature. 2012;482:30.

38. Bubová T, Vrabec V, Kulma M, Nowicki P. Land management impacts on European butterflies of conservation concern: a review. J Insect Conserv. 2015;19(5):805-21.

39. Zakkak S, Radovic A, Nikolov SC, Shumka S, Kakalis L, Kati V. Assessing the effect of agricultural land abandonment on bird communities in southern-eastern Europe. J Environ Manag. 2015;164: $171-9$.

40. Navarro ML, Proença V, Kaplan OJ, Pereira MH. Maintaining disturbance-dependent habitats. In: Pereira MH, Navarro ML, editors. Rewilding European landscapes. Cham: Springer International Publishing; 2015. p. 143-67.

41. Cerqueira Y, Navarro ML, Maes J, Marta-Pedroso C, Pradinho Honrado J, Pereira MH. Ecosystem services: the opportunities of rewilding in Europe. In: Pereira MH, Navarro ML, editors. Rewilding European landscapes. Cham: Springer International Publishing; 2015. p. 47-64.

42. Navarro ML, Pereira MH. Rewilding abandoned landscapes in Europe. In: Pereira MH, Navarro ML, editors. Rewilding European landscapes. Cham: Springer International Publishing; 2015. p. 3-23.

43. Hartig T, Mitchell R, de Vries S, Frumkin H. Nature and health. Annu Rev Public Health. 2014;35(1):207-28.

44. Heinztman P. Spiritual outcomes of park experience: a synthesis of recent social science research. George Wright Forum. 2013;30:271-9.

45. Arts K, Fischer A, van der Wal R. Boundaries of the wolf and the wild: a conceptual examination of the relationship between rewilding and animal reintroduction. Restor Ecol. 2016;24(1):27-34.

46. Lorimer J, Driessen C. Wild experiments at the Oostvaardersplassen: rethinking environmentalism in the Anthropocene. Trans Inst $\mathrm{Br}$ Geogr. 2014;39(2):169-81.

47. Agnoletti M. Rural landscape, nature conservation and culture: some notes on research trends and management approaches from a (southern) European perspective. Landsc Urban Plan. 2014;126:66-73.

48. Linnell JDC, Kaczensky P, Wotschikowsky U, Lescureux N, Boitani L. Framing the relationship between people and nature in the context of European conservation. Conserv Biol. 2015;29(4): 978-85.

49. Katayama N, Osawa T, Amano T, Kusumoto Y. Are both agricultural intensification and farmland abandonment threats to biodiversity? A test with bird communities in paddy-dominated landscapes. Agric Ecosyst Environ. 2015;214:21-30.

50. Tsiafouli MA, Apostolopoulou E, Mazaris AD, Kallimanis AS, Drakou EG, Pantis JD. Human activities in natura 2000 sites: a highly diversified conservation network. Environ Manag. 2013;51:1025-33.

51. Pereira MH, Navarro ML. Preface. In: Pereira MH, Navarro ML, editors. Rewilding European landscapes. Cham: Springer International Publishing; 2015. p. v-X.
52. Deinet S, Ieronymidou C, McRae L, Burfield IJ, Foppen RP, Collen B, et al. Wildlife comeback in Europe: the recovery of selected mammal and bird species. London: Zoological Society of London; 2013.

53. Chapron G, Kaczensky P, Linnell JDC, von Arx M, Huber D, Andren H, et al. Recovery of large carnivores in Europe's modern human-dominated landscapes. Science. 2014;346(6216):1517-9.

54. Bradley EH, Robinson HS, Bangs EE, Kunkel K, Jimenez MD, Gude JA, et al. Effects of wolf removal on livestock depredation recurrence and wolf recovery in Montana, Idaho, and Wyoming. J Wildl Manag. 2015;79(8):1337-46.

55. Thulin CG, Malmsten J, Ericsson G. Opportunities and challenges with growing wildlife populations and zoonotic diseases in Sweden. Eur J Wildl Res. 2015;61:649-56.

56. Hayward MW, Ortmann S, Kowalczyk R. Risk perception by endangered European bison Bison bonasus is context (condition) dependent. Landsc Ecol. 2015;30(10):2079-93.

57. Wilson S, Davies TE, Hazarika N, Zimmermann A. Understanding spatial and temporal patterns of human-elephant conflict in Assam, India. Oryx. 2015;49(1):140-9.

58. Ziółkowska E, Perzanowski K, Bleyhl B, Ostapowicz K, Kuemmerle T. Understanding unexpected reintroduction outcomes: Why aren't European bison colonizing suitable habitat in the Carpathians? Biol Conserv. 2016;195:106-17.

59. D'Amico M, Periquet S, Roman J, Revilla E. Road avoidance responses determine the impact of heterogeneous road networks at a regional scale. J Appl Ecol. 2016;53(1):181-90.

60. Balmford A, Green R, Phalan B. Land for food \& land for nature? Daedalus. 2015;144(4):57-75.

61. Phalan B, Green RE, Dicks LV, Dotta G, Feniuk C, Lamb A, et al. How can higher-yield farming help to spare nature? Science. 2016;351(6272):450-1.

62. Jørgensen D. Rethinking rewilding. Geoforum. 2015;65:482-8.

63. Boitani L, Linnell CJD. Bringing large mammals back: large carnivores in Europe. In: Pereira MH, Navarro ML, editors. Rewilding European landscapes. Cham: Springer International Publishing; 2015. p. 67-84.

64. Cornelissen P, Bokdam J, Sykora K, Berendse F. Effects of large herbivores on wood pasture dynamics in a European wetland system. Basic Appl Ecol. 2014;15(5):396-406.

65. Sandom CJ, Hughes J, Macdonald DW. Rewilding the Scottish Highlands: Do wild boar, Sus scrofa, use a suitable foraging strategy to be effective ecosystem engineers? Restor Ecol. 2013;21(3): 336-43.

66. Smit C, Ruifrok JL, van Klink R, Olff H. Rewilding with large herbivores: the importance of grazing refuges for sapling establishment and wood-pasture formation. Biol Conserv. 2015;182:134 42 . 